\title{
The Role of Women towards Political Participation in Nigeria
}

\author{
Ibrahim Suleiman ${ }^{1}$ \\ ${ }^{\mathbf{1}}$ Department of Political Science, Bauchi State University, Gadau, Nigeria \\ Correspondence: Department of Political Science, Bauchi State University, Gadau, Nigeria, Tel: \\ +2348060287718, E-mail: isuleiman@basug.edu.ng
}

Received: September 28, 2017

Accepted: September 30, 2017

Online Published: October 3, 2017

\begin{abstract}
This study investigates the factors that limit women's participation in Nigeria's politics using case study period between 1999 and 2015, among these factors are socioeconomic development, the country's cultural heritage, historical legacies and institutional designs. The study employs secondary source as a method ofdata collection. The study reveals that the patriarchal system and male domination of the society, which relegates women to subordinate role, has created women's inferiority complex and alienated them from the mainstream politics in Nigeria. The Nigerian political culture of thuggery and gangsterism has made the political terrain too dangerous for most women to venture into mainstream politics. Besides, the stigmatization of women politicians by fellow women discourages the political participation of the former while religious beliefs and institutional arrangements that restrict women to family responsibilities in the country coupled with lack of genuine and decisive affirmative action to encourage women's political participation, have created a legacy that limit women's political participation in the country as a whole. Consequently, the study emphasizes the need to address those factors that entrench women subordination in Nigeria's politics. These include, among others, the reformation of all religious, statutory and customary laws and practices that perpetuate women's subordination in the country and the explicit specifications and modalities of affirmative actions on women's political participation and clear guidelines for implementations in the Nigeria constitution.
\end{abstract}

Keywords: Political Participation, Women Participation \&Factors affecting Women Political Participation in Nigeria.

\section{Introduction}

The increasing salience of women's issues and the resurgence of women's movements have raised popular consciousness and intense academic discourse on poor participation of women in politics (Peterson \& Ruyan, 1999: 48 \& Akinboye, 2004:233). Though women's low political participation is a universal phenomenon (Shaul, 1982; Waylen, 1996:11; Akinboye, op.cit:233; Lewu, 2005:62; Rai, 2005 \& Pokam, 2006), the imperative of women participation in democratic governance and human development cannot be over emphasized (Amadiume, 1997:81; Bruce, 2004:113; Babatunde, 2003; Bari, 2005). Sustainable democratic government relies upon the participation of all citizens in determining through elections and political processes, 
who governs them. It also depends upon the equality of all citizens under the law (Sodaro, 2001:247, Anifowose, 2004:205). Women's legal status is closely linked with their political participation and has an impact on their ability to contribute to and benefit from economic and social progress. The involvement of women in political activities underscores this correct assertion:

Without the active participation of women and the incorporation of women's perspective in all levels of decision making, the goals of equality, development and peace cannot be achieved (Akiyode; Afolabi \& Arogundade, 2003).

The possibility for all citizens - both males and females to participate in the management of public affairs otherwise known as mass or popular participation is thus at the very heart of democracy (Sodaro, 2001:247). Putting it more succinctly, the Inter-Parliamentary Union incorporated in the Universal declaration for Democracy that:

The achievement of democracy presupposes a genuine partnership between men and women in the conduct of the affairs of society in which they work in equality and complementarity drawing mutual enrichment from their differences (Inter-parliamentary Union, 1999).

Although equal political opportunity for women is a goal shared by both men and women and despite increased support of women's equality, for thousands of years, women records poor participation in politics and decision making positions (Waylen, op.cit:10; Anifowose, 2004:204; Pokam, 2006; Henderson, 2006). This is despite the fact that women constitute roughly half of the current world population (Pascaud-Becane, 1999; Babatunde, 2003; Anifowose, op.cit:204; Bari, 2005). In Nigeria, like in other parts of the world, women are at least half the country's population. According to the report of the 2006 Census, women constitute $48.78 \%$ of the national population, yet this numerical strength of women does not automatically translate to increase in women's participation in political activities in the country (Kukah, 2003:162; Abdu, 2003; Nigeria CEDAW NGO Coalition Shadow Report, 2008).

While the global average representation of women in national politics is $10 \%$, in Nigeria, the figure has hardly ever been more than 3\% (Ajayi, 2007:138; Inter-parliamentary Union, 2007). From the country's independence to 48 years after, there have been various degrees of women's participation in politics and governance and varying sets of limiting factors to women's political participation (Johnson, 2003; Agomo, 2004; Adu, 2008).

This global low women's participation in politics has prompted the emergence of campaigns to increase women's political presence in countries around the world. The first major international action in favour of women universally was taken by United Nations in 1946 when it set up a commission on the status of women (Peterson \& Runyan, 1999:11; Akiyode-Afolabi et al, 2003). In 1975 during the International Women's Year, the UN General Assembly launched the UN Decade for Women (1976 - 1985) with a view to creating greater global awareness on the status of women and the girl child (Akinboye, 2004:13). This concern climaxed with the Fourth World Conference on Women in 1995 held in Beijing, China with the theme "Equality, Development and Peace", the aim of which was to review and appraise the achievements of the UN Decade for Women (Omotola, 2007:33). One of the major activities of the year was the World Conference on Women that took place in Mexico.

In 1976, the UN Assembly again established the Voluntary Fund for the UN Decade for Women to implement the objectives of the Decade (Oyekanmi, 2004:44). It also adopted the Convention on the Elimination of All forms of Discrimination Against Women (CEDAW), which became effective in 1981 (Rai, 2005:3). In 1985 however, the General Assembly gave the Organization an expanded mandate to join the UN group of agencies as the United Nations Development Fund for Women (UNIFEM) with the mission to promote the economic 
and political empowerment of women in developing countries. In addition, the Organization of African Unity (OAU) and the New Partnership for Africa's Development (NEPAD) work towards strengthening women's political leadership and their participation in political decision-making bodies (Olojede, 2004:120). These events marked a watershed in human resource development as it brought women, the other half of the world's population, into development.

However, despite these international instruments to encourage women involvement in political activities, the world still witnesses slow progress of women participation in politics (UNDP Report, 2005). The Inter-Parliamentary Union Report of 2007 indicates that there are onlytwelve countries where women attained the critical mass of $30 \%$ women representation in the parliament, out of which Rwanda, Sweden Finland, Argentina are handful of countries that have elected more than $40 \%$ women to their legislative body (IPU, 2007).

\section{Political Participation: A Conceptual Discourse}

A conceptual analysis of citizens' participation in politics will not be thorough without a clarification of what constitutes politics. This section therefore briefly considers the concept of politics.

\subsection{The Concept of Politics}

The concept of politics has been viewed in different perspectives by scholars who have written on the subject matter. Heywood (1997:1) confers his credence to the divergent views of scholars on the concept of politics when he noted that respected authorities can not agree on what the subject matter is all about. In this vein therefore, the term politics has been defined in various ways. The idea of Aristotle that 'man is by nature a political animal' and his conclusion that politics is the 'master science' because it involves the intricacy of conflicts and conflicts resolution on the distribution of power and resources in the society readily comes to the fore. Heywood (1997:10) inextricably linked politics to the phenomenon of conflict and cooperation when he defined politics as the art of government, a phenomenon which relates to public affair, a means of resolving conflicts either by compromise, conciliation or negotiation, rather than through force and naked power. Sodaro (2001:27) share this view by defining politics as the process by which communities pursue collective goals and deal with their conflicts authoritatively by means of government.

Easton (1990) defines politics as the 'authoritative allocation of values' in a political system. By this Easton sees politics as encompassing the various processes through which government responds to the pressures and demands of allocating benefits, rewards or penalties in a society. This is why Lasswell (1958) sees politics as the determination of who gets what, when and how. It is however observed that the various definitions above consider the concept of politics from the view point of the normative function of politics which is the resolution of conflict of interests. However, it is necessary that its inscriptive value be also put to bear. In doing so, the concept of politics will not just be limited to the view of the developed countries but will also be relevant to the context of the developing countries particularly Africa. The holistic approach to the concept of politics is however observed by Williams (1980:69) in his view of politics from two perspectives. Firstly, that politics is a discreditable activity whose virtue is the competitive pursuit of private interests and secondly, that politics is concerned with the administration of the common affairs of the public, a matter of universal rather than particular concern, whose aim is defining and promoting the common goods. The opinion of Sodaro (2001:27) that politics is a process connotes its continuing sequence of events and interactions among various actors (individuals, organisations and government) which generally take place within a structure of rules, procedures and institutions rather than haphazardly. The indispensability of politics to the existence of statehood makes Appadorai (1974:4) to conclude that politics is "the science which is concerned with the state and of the 
condition essential for its existence and development'.

Following this view therefore, Dahl (1963) defines politics as any stable pattern of human relationships that involves power and influence. While all the above conceptual definitions of politics portray the view of these writers as it relates to the theme under discussion, one finds the basic thrust of politics from these various scholarly views. In this regards therefore, politics involves such issues as the exercise of power or authority, a collective decision making process, allocation of scarce resources among contending factors, the making and preserving of rules and the practice of deception and manipulation. The fact that politics permeates every aspect of life owes to Aristotle's submission that 'it is only within a political community that human beings can live the good life.' It is imperative to grasp the truth that all social problems are in one way or the other linked to political decisions of the powers that be, a participation in this essential ingredient of a political system is therefore very much a necessity (Kumari \& Kidwai, 1994: 11).

\subsection{The Concept of Political Participation}

Political participation is an essential component that is required for ensuring the stability and legitimacy of every political system (Kumari \& Kidwai, op.cit: 12). According to Agbaje (1999:193), political participation is one of the fundamental ideas of a democratic society. It is the sine qua non of democracy, because democracy involves a commitment to equal opportunity for men and women to develop their individual capacities (Anifowose, 2004:205). Thus, democracy is inconceivable without political participation (Agbaje, 1999:193). According to Pateman (1970) however, citizens' participation in politics is very important because it determines how much power is controlled. Thus in the view of Kumari \& Kidwai (1999:12), in every society, the wielders of political power are very keen on ensuring at least some amount of political participation by the people. Political participation therefore, describes the extent to which individual members of society share, take part or get involved in the life of that society (Agbaje, 1999:193). It is because of this crucial place that political participation holds that Kumari \& Kidwai (1999:13) asserts that its denial to substantial part of the population can result to explosive situation. Consequently, the political power that women or any group of persons in a society have would be linked directly to the degree of their participation in the political process of that society (Lewu, 2005:63). Theoretically, political participation has a long genealogy.

Like most concepts that are used today, it is an unfolding concept. From direct participation of the Greek city-states to the Schumpeterian rejection of that model, the concept has been central to every discussion about democracy (Beck, 1997). Though the search for a participatory, just and sustainable society permeates all political systems, the normative question of how much ordinary people should participate and what kind of popular participation in political affairs is possible and desirable, is very much politically relevant and socially significant (Bruce, 2004:106). This question owes to the fact that the term "participation" though widely used within democratic theory, its meaning remains vague (Weale, 1999:84). Steiner (1988) posits that the question of what it is to take part in politics is massively complex and ultimately ambiguous. He noted that while it is assumable that activity within a political party or an organisation which regarded itself as a pressure group should count as political participation, activity in other sorts of organisation, such as sports associations and traditional women's organisation which are though not overtly political but set the contexts of politics, give their active members administrative experience and are capable of overt political action if their interests or principles are threatened remains ambiguous as to whether those activities are political or not.

Anifowose (2004:205) defines political participation as those voluntary activities such as holding public and party office, being a candidate for office, attending election campaigns, voting and exposing oneself to political stimuli. Similarly, Maclosky (1968) defines political participation as a series of voluntary activities through 
which members of a society share in the direct or indirect selection of rulers and formation of public policy. Sanghera, (2005) on the other hand defines political participation as the active engagement by individuals and groups with the governmental processes that affect their lives. This encompasses both involvements in decision-making and acts of opposition.

\subsection{Women and Political Participation}

Throughout the world, the power relations that shape social, political, economic and cultural life prevent women from participating fully in all areas of their lives, whether it's in the home, or in the public arena (Awe, 1992; Waylen, 1996; Nwankwo, 1996, Unumeri, 2003, Abdu, 2003, Johnson, 2003). According to Akioyede-Afolabi (2003), the global average representation of women in national politics is 5\%. Notable exceptions include the Nordic countries, Costa Rica, South Africa and Uganda, where proportional representation is practiced (Lewu, 2005:62; IPU Report, 2007). While women's dedicated efforts to challenge the status quo have allowed more women to reach positions of power in recent years, women continue to be under-represented in all areas of decision-making, such as religion, the media, culture and the law and still face significant barriers to their full and equal participation in the structures and institutions which govern their lives (Omotola, 2007; Ajayi, 2007; The Nigeria CEDAW NGO Coalition Shadow Report, 2008; Genevieve, 1999). The first ever women rights convention (which had more than one hundred women in attendance was held in 1948 at Seneca falls, New York at the instance of women like Lacretia Moth and Elizabeth Candy Stanton. The group demanded equal rights, including voting right and an end to double standard. New Zealand was the first country to allow women to vote in 1893.

In the United States of America however, women did not enjoy franchise until 1920, and similarly, Britain did not allow women franchise until 1928. This political right of women in France was not allowed until 1944, while Italy, 1945 and China 1947. Nigerian women enfranchisement came in 1959 while in Switzerland women were not allowed to vote until 1971 (Ajayi, 2004:138). For the first time in history in 1919 the American born Lady Nancy Astor became the first elected women to take her seat in the British parliament after fulfilling certain age and property (Johnson, 2003). Several national and international documents and human rights mechanisms have been put forward to encourage women's participation in politics including the International Convention on Civil and Political Rights (1966) and the International Convention for the Elimination of All Forms of Discrimination Against Women (1979), elaborate the nature of women's civil and political rights and the steps required to promote greater equality between women and men in this area (Kukah, 2003:163; Akinboye, 2004:13). The Beijing Platform for Action, the principal international action plan on women's rights, contains a section on women in power and decision-making, which states that the empowerment and autonomy of women and the improvement of women's social, economic and political status is essential for the achievement of both transparent and accountable government and administration and sustainable development in all areas of the society.

On the other hand, since the post-World War II era, there has been a global explosion of women's activism on behalf of equality, liberation, and better living conditions. They have gained visibility and influence in a wide array of political and economic arenas in the society. This change seems to allow many women to go further; by building up their own careers and support bases, consequently becoming actively involved in politics in their own right. Thus women's increasing political participation is both a source and a signal of social change (Henderson, 2006). Paradoxically however, despite the increasing involvement of women in political activities and the acknowledged women's crucial role in nation building, the prevailing trend witness a seeming aberration which put limitations on women participation in political activities (Akinboye, 2004:14). Most 
countries of the world still fall short of the critical mass of $30 \%$ of women political representation (IPU, 2005).

\subsection{Legal Framework for Women's Political Participation}

Human rights, an old concept, are considered to be universal and inalienable, individual, indivisible, interrelated and interdependent. It is a general notion embracing rights that are applicable to individuals, peoples and mankind (Agomo, 2004:92). The foundational legal articulation of this right can be found in Article 21 of the UN's 1948 Universal Declaration of Human Rights. This has been further formalized and elaborated in the later treaties most notably the 1976 International Covenant on Civil and Political Rights (Adu, 2008). Klein (2005) argues that the Declaration is a statement of general principles and since it is not a treaty, the standards of behaviour that it defines have the status of only non-binding norms, but the document is nonetheless of enormous legal and political importance, for it provided the foundation not only for later legal-binding international treaties but also for many national governments' rights frameworks. However, the Covenant which was ratified almost three decades after the Declaration as a treaty imposes some obligations on signatory states and includes some compliance mechanisms. The right to representation and politics of inclusion are the hallmark of civil and political rights (Bruce, 2004:105). Klein (2005) defines the right to political participation as citizen's right to seek to influence public affairs. The right to political participation is spelt out in both Article 21 of the Declaration and Article 25 of the Covenant. Article 21 of the Declaration states that:

(1)Everyone has the right to take part in the government of his country, directly or through freely chosen representatives. (2) Everyone has the right of equal access to public service in his country. (3) The will of the people shall be the basis of the authority of government; this will shall be expressed in periodic and genuine elections which shall be by universal and equal suffrage and shall be held by secret vote or by equivalent free voting procedure (cited in Wilkipedia, 2008).

\subsection{Similarly, Article 25 of the Covenant States}

Every citizen shall have the right and opportunity, without unreasonable restrictions: (a) to take part in the conduct of public affairs, directly or through freely chosen representatives; (b) to vote and be elected at genuine periodic elections which shall be by universal and equal suffrage and shall be held by secret ballot, guaranteeing the free expression of the will of electors (quoted in Steiner, 1988). According to Klein (2005), the political right as spelt out in these two Articles deserves special attention. Whereas the other rights are recognised as natural part of human beings, the Declaration recognises political rights within the confine of government and similarly the Covenant limits the right to political participation to those with the status of citizen. Since citizenship is recognised only within the context of a government and a political community, the right to political participation presupposes a political community with individual members (citizens) and organizational form (government). Since the Declaration and the Covenant conditioned political right on the existence of political institutions, it is concluded that the rights to participation does not exist as a human right per se but only in the context of a political institutions of citizenship and government. Women's civil and political rights are integral parts of the larger human rights agenda (Bruce, 2004:105).

The legal framework for women' participation in politics is therefore an integral part of the political rights spelt out above in the Article 21 and Article 25 of the Declaration and the Covenant respectively. The legal framework for women's participation in politics is however, given more vivid expression by some specific international mechanisms and conventions instituted to enhance women's involvement in politics. The International Convention on Civil amd Political Rights and the International Convention for the Elimination of All Forms of Discrimination Against Women of 1979 (CEDAW), elaborates the nature of women's civil and political rights and steps required to promote greater involvement of women in politics (Okome, 2006). The 
convention in its Article 1 bars any distinction, exclusion or restriction made on the basis of sex which has the effect or purpose of impairing or nullifying the recognition, enjoyment or exercise by women, irrespective of their marital status, on the basis of equality of men and women, of human rights and fundamental freedoms in the political, economic, social, cultural, civil or any other field. As defined by the convention, discrimination is symptomatic of a situation where patterns of structural inequality are maintained by rules, norms and procedures that dictate a subordinate role for women in all spheres of society. It stresses the need for a holistic orientation which acknowledges the vital role of women in development and engineers their integration into development processes as equal partners with men (Okome, 2006).

Nigeria signed the convention on 23rd of April 1984 and ratified it without any reservations on 13th of June, 1985, and it ratified the optional protocol to CEDAW on the 8th September, 2001 (Okome, op.cit; Chikwe, 2003). The participation of women in politics and decision-making is one of the central areas of focus of the Beijing Declaration and Platform for Action (1995), the principal international action plan on women's rights. It reiterates the importance of women empowerment and the improvement of their social, economic and political status to the achievement of both transparent and accountable government and administration and sustainable development in all areas of life (Bari, 2005). This is reaffirmed in Goal No.3 of the Millennium Development Goals (MDGs) in year 2000 which aims at promoting gender equality and empowering women through eliminating gender disparity at all levels by year 2015. The indicators include - ratios of girls to boys in primary, secondary and tertiary education, share of women in wage employment in the nonagricultural sector and proportion of seats held by women in national parliament (Omotola, 2007:33; UNDP, 2008; Wilkipedia, 2008) Nigeria is also a signatory to the Beijing Declaration and Platform for Action adopted by the Fourth World Conference on Women held in Beijing on the 15th of September 1995. The Declaration aims at achieving greater equality and opportunity for women by removing the obstacles to women's public participation in all spheres of public and private lives through a full and equal share in economic, social, cultural and political decision-making. On the basis of that adoption, the Nigerian Government constituted the National Committee on Affirmative Action (Wikipedia, 2008; Anifowose, 2004:210). Furthermore, the National Policy on Women was adopted by the Federal Government of Nigeria in the year 2000. The goal of the policy centres on enhancing the active and meaningful participation of women in the political arena by eliminating all forms of legal, cultural, religious and other discrimination against women, empowering them through enhanced strategic human resource development, integrating women in all sectors of development in accordance with their capabilities and needs and establishing a data bank on the implementation of a comprehensive (national) baseline survey (Chikwe, 2003; Olojede, 2004:120). At the national level however, the legal framework for women's participation in politics in Nigeria is, hinged on the provisions of the Constitution of the Federal Republic of Nigeria. The 1999 constitution of the Federal Republic of Nigeria by virtue of Section 40 guarantees the political rights of every citizen of the country. It states that:

Every person shall be entitled to assemble freely and associate with other persons, and in particular he may form or belong to any political party, trade union or any other association for the protection of his interests... Section 42 of the same constitution states further that: Any citizen of Nigeria of a particular community, ethnic group, place of origin, sex, religion or political opinion shall not, by reason only that he is such a person be subjected to any form of discrimination. Section 77(2) also confers the right to register and to vote for the purpose of election on every citizen that has attained the age of 18 years. A key policy document that supports women's participation in political and public life is the National Gender Policy 2006. The 5th objective of the policy is aimed at achieving minimum threshold of representation for women in order to promote equal opportunity in all 
areas of political, social economic life of the country for women and men (The Nigerian CEDAW NGO Coalition Shadow Report, 2008). The legal framework for women's participation in politics, Nigeria inclusive, is thus premised on the ground that women possess the same rights as men to participate in governance and public life (Akiyode-Afolabi, 2003, Babatunde, 2003).

There are a number of factors put forward to explain participation of women in politics. These factors are critically perused in the next section.

\section{Factors Affecting Women's Political Participation}

Women's participation and access to formal political power structures vary across countries (Bari, 2005). Recent literatures on women and politics have identified various factors that affect women's participation in politics across the globe. Of the factors explored, research finds the following four factors to be particularly important: (1) socioeconomic development; (2) cultural factor; (3) historical legacies stemming from a society's cultural and political traditions; and (4) institutional design factors (Amadiume, 1997; Inglehart \& Noris, 2003, Akioyode-Afolabi, 2003; Dahlerup, 2005; Rai, 2005; Alexander \& Welzel, 2007).

\subsection{Socioeconomic Development}

Alexander \& Welzel (2007) refer to this as economic modernity. This is the view of the classical development. It focuses on economic development and considers increases in democracy and human choice as direct outcome of economic development (Lipset, 1959; Rostow, 1960; Bell, 1999; Ineles \& Smith, 1974). In relations to gender equality, this approach holds that economic development is central to increasing the pool of women eligible for positions of social power (Alexander \& Welzel, 2007). Thus Babatunde (2003:6) argues that a country's level of development correlates with women's participation in politics and decreases existing barriers to political activity and participation. These scholars establish that increased economic development associates with a more broad based distribution of educational and occupational resources. Greater access to educational and occupational resources increases women's chances of professional development, creating a larger pool of women eligible for power positions such as political office. Others note that higher levels of economic development bring more social services to societies. These developmental measures such as increase in per capita, gross domestic product, women in the work force and women literacy positively influence the percentage of women's political participation (Kenworthy \& Malami, 1999; Reynolds, 19999, Welch \& Studler, 1996; Babatunde, 2003).

\subsection{Cultural Factor}

Cultural norms and customary practices have great influence on women's political participation. Babatunde (2003) defines culture as a socially created phenomenon that is influenced by the history, social experiences and material circumstances of the people. Among the cultural ideological factors that affect women's political participation is patriarchy system (Bari, 2005). Patriarchy is characterized by male kinship, permanent marriage and paternal authority (Appadorai, 1974:35). Fayomi \& Igbelina-Igbokwe (2006) note the influence of patriarchy cultural structure on the social status of the female gender. Cain, Khan \& Nahar (1979:406) define patriarchy as a set of social relations with a material base that enables men to dominate women. Here, the central focus of power is the father, and the factual importance of motherhood kinship structure and history is denied (Amadiume, 1997:72).

In other words, patriarchy describes a distribution of power and resources within the family in a manner that men maintain power and control of resources, and women are powerless and dependent on men (Oyekanmi, 2004:42). Thus, men dominate the political game, and set the standards for evaluation. This negative factor entrench feelings of inferiority complex and other vices that perpetually put women at a disadvantaged position 
(Akinboye, 2004:237). Additionally, research finding shows gender role ideology which does not only create duality of femininity and masculinity, but also places them in hierarchical fashion in which women are subordinated to men. Women also find it hard to participate in politics due to limited time available to them because of their dual roles in the productive and reproductive spheres (Bari, 2005). Alexander \& Welzel (2007) and Inglehart \& Noris (2003) however, note a rising gender-egalitarian attitudes that gives rise to an emancipative worldview, reflected in self-expression values that emphasize autonomy of women. According to these scholars, this rise in emancipative orientations consequently leads to increase in women's empowerment and political participation throughout society. This perspective highlights changes in modern societies particularly conducive to women's empowerment and therefore establishes a link between cultural factor and women involvement in public life. Inglehart \& Norris (2003) find that cultural factor holds real, positive consequences for women empowerment and thus women's political participation.

\subsection{Historical Legacies}

Researchers have presented historical legacies potentially capable of affecting women's social and political status (Omotola, 2007:38). Scholars argue that a country' developmental trends of social modernization create cultural and institutional legacies that affect societies' abilities to improve women's lives (Krasner 1984; Skocpol 1992). Alexander \& Welzel (2007) note that the emergence of institutions, whether cultural or the result of policy, sometimes consists of types of social organization that have a continuing and somewhat determinant influence on phenomena relevant to those institutions far into the future. This influence can take the form of an inertial tendency where institutions affect relevant phenomena that would have otherwise changed due to other social forces (Peters 1999). This view considers some measures of path dependent processes capable of affecting gender equality: Protestant religious traditions, a long tradition of female suffrage, colonialism and a state tradition of investing into welfarism rather than coercive forces.

Depending on the nature of a society's traditions, religions vary in opportunity for women's emancipation (Amadiume, 1997; Inglehart \& Norris 2003). For instance, relative to other religious heritages, scholars find that a Protestant religious heritage improves the status of women in a country. Protestantism holds a tradition particularly hospitable to democratic values, such as respect for individualism, reciprocity and popular sovereignty (Inglehart, Norris \& Welzel 2002; Inglehart \& Welzel 2005; Reynolds 1999; Rule 1987). Researchers also approach the impact of religious legacy on women's empowerment through measures of publics' levels of secularization (Inglehart \& Norris 2003; Inglehart \& Welzel 2005). As societies secularize there is greater deference to rationality and expertise, and this typically gives rise to the modern state and widespread social services. The secularizing trend typically occurs from the pre-industrial through the industrializing phase of modernization. During this transition, traditional units restrictive of women's development such as the family and the church lose their authority as individuals place greater emphasis on rationality and individualism (Inglehart \& Norris 2003; Inglehart \& Welzel 2005).

In addition to religion, path dependent processes with respect to women's suffrage policy may affect the potential to increase women's political participation in particular societies. Some studies have also stressed the salience of the epoch character of colonialism particularly in African countries. They have argued that colonialism in Africa was male dominated and did nothing to deviate from the preclusion of women from the public sphere and their limitation in the economic sphere (Omotola, 2007:38). Countries with earlier suffragist policies for reforming women's formal political exclusion are likely to have a stronger institutional legacy of women's formal political inclusion (Kenworthy \& Malami 1999; Moore \& Shackman 1996; Ramirez, Soysal \& Shanahan 1997; Rule 1981). 
State-financed welfarism policy is another central factor to societies' progress in political participation by women. Much research confirms that a key barrier to women's full social inclusion and autonomy has been and continues to be institutional arrangements that restrict the state's role in caretaking and domestic responsibilities (Hirschmann 2001; Liebert 1999; Sainsbury 1996; Tronto 2001). Welfare policy is capable of alleviating these barriers by expanding the scope of the state's involvement in these everyday household necessities through, for instance, state supported childcare. Thus, state legacies with respect to welfare policies are an additional form of historical institutionalism that could potentially offset the empowerment modernization brings to women.

\subsection{The Institutional Design Factor}

This view holds that a country's institutional characteristics either enable or constrain women's political participation (Alexander \& Welzel, 2007). Three aspects of the political system find support in this literature: the strength of democracy, the electoral system, and gender electoral quota systems. Thus Inglehart \& Norris (2003) submit that democratic institutions that preserve and socialize free and equal citizenship supply women with more rights and more channels for making their voices heard (Alexander \& Welzel, 2007).

The impact of institutional variation within democracies on women's political involvement has also been considered. Most prominent among the arrangements considered is the influence of electoral systems (Krook, 2008). Electoral systems affect women's paths to parliament by structuring party elites' incentive or disincentive to run women candidates. In this regard therefore, proportional representation system has been found to have a positive impact on the percentage of women in parliament (Pascaud-Becane, 1999; The Nigeria CEDAW NGO Coalition Shadow Report, 2008; Rai, 2005; Kenworthy \& Malami 1999; Lakeman 1994; Norris 1985; Paxton 1997; Akioyede-Afolabi, 2003).This is because these electoral systems have a higher number of seats per district and offer parties a greater chance of winning more than one seat per district.

Moreover, through greater district magnitude and party magnitude, parties are more likely to choose women candidates for the second seat (Matland 1993; Rule 1994). Thus, because Proportional Representation electoral systems increase women's chances of recruitment and electability despite lower placement on candidate lists, these electoral systems provide greater opportunity for the election of women. Finally, with Proportional Representation electoral system, the greater incentive to balance tickets gives parties greater opportunity to promote gender as an option for challenging other parties. This typically results in a promotion of women's inclusion across parties as elites attempt to equalize the playing field by avoiding the appearance of their party's marginalization of women voters (Matland \& Studlar 1996; Akioyode-Afolabi, 2003). As noted by Matland (2004), there is a distinct gap in women's representation in national legislatures between countries with single-member district electoral systems and those with proportional representation electoral systems.

In addition to the role of electoral rules, gender electoral quota systems are institutional mechanisms that consistently, positively mediate the conditions and attitudes that structure women's leadership potential. Indeed, researchers studying the recent proliferation of quota systems throughout the world have referred to quota systems as "the fast track" to the equal political representation of women (AkioyodeAfolabi, 2003). Over the last three decades, several societies beginning with Norway, have introduced some form of a gender electoral quota system in their political bodies for improving the status of women. These quota systems take the form of a constitutional amendment, electoral law or party policy. Scholars generally find that the stronger the gender electoral quota system the greater the level of women's percentages in political office (Dahlerup \& Freidenvall 2003; Caul1999, 2001; Kolinsky 1991; Matland 1993; Studlar \& Macalister 1998). Thus the attributes of democratic institutions, electoral systems, and the degree to which countries adopt gender electoral quota 
systems are the institutional designs that perform mediating role of either improving or hindering women's presence in political office (Dahlerup 1998; Babatunde, 2003).

Taking the four factors as a whole, economic development, socio-cultural factor, together with historical legacies, as well as various institutional design factors are the likely correlates of various aspects of women's participation in politics. What is less clear however, is the degree to which these four factors uniquely influence women's participation in political activity. This therefore necessitates a comparative assessment of the same cultural and political predictors on women's participation in Nigerian politics to confirm the relative degree to which the political environment matters with respect to women's attainment of positions of full political empowerment. It is useful to ask whether and to what extent economic development, socio-cultural factor, historical legacies and institutional designs uniquely influence women's prominence in Nigerian politics.

\section{Womens' Political Participation in Nigeria: Historical Background}

\subsection{Pre-Colonial Period}

Prior to their colonial experience, the Nigerian women played active and productive roles in their respective traditional political governance (Akinboye, 2004:236; Ajayi, 2007). Although women's political participation during pre-colonial era was not equal to that of men, the position of women in governance was complementary rather than subordinate (Mba, 1982:37; Nwankwo, 1996:20 \& Ikpe, 2004:23). Even in the most conservative of societies of Nigeria, women contributed tremendously to the development of their societies (Awe, 1992:11). In the pre-colonial Nigeria, they occupied important roles in the traditional political life and in their different regions, they were actively engaged in politics and held decision-making roles in the governmental institution in their respective regions (Kamene, 1991). The extent of women's participation in the public sphere in the pre-colonial Nigeria however, depended very much on how their particular society was organized, whether in the form of monarchy like the Yoruba kingdom or as republican like the Igbo tribes (Nwankwo, 1999:14). The traditional Nigerian society was segregated between genders which enabled the measurement of power and achievements. The complementarity's role of women was however embedded in sex segregation, which determined gender position, status and power in the society and provided them their own spheres of operation and control (Ikpe, 2004:22). Certain political structures, which allowed for power sharing between men and women were articulated and firmly put in place. Women for instance, had access to political participation through a complex and sophisticated network of relationship, rights and control of power with men in certain societies, their role were complementary or subordinate in others (Olojede, 1990:82).

This however, does not mean that women occupied equal roles with men in the society. There were very few women who possessed political power in the precolonial Nigeria (Awe, 1992). Only very few women were initiated into traditional cults such as Ogboni, Osugbo, Ekpo, Ekpe, Eyo, etcetera. (Ojuolape, 2001:1) Some notable women in the traditional political governance in the South West Nigeria include the Erelu, Ayaba and Olori (king's Wives", Iyalode (Women's Leader), Iyalaje (Market Women's Leader), Yeye Oba (King's Mother) and Iya-olosa (Goddess priests), Moremi of Ife, Efusetan of Ibadan and Emotan. One cannot undermine the significant role of Iya Afin, Iya Agan and Iya Abiye to the palace administrations of the various kingdoms (Mba, 1982; Nwanckwo, 1999:14) Likewise, the influence and contributions of Queen Amina of Zaria to the political development of the Northern Nigeria's emirate and the achievement of Kambasa of Bony in the dim pre-colonial past are by no means negligible (Awe, 1992). The change of government from the Hausa aristocracy to the Fulani/Muslim hegemony however, totally excluded women from the public sphere. After the reign of Amina in the pre-Islamic past of Zaria, there was no woman who sat in the court of any Hausa ruler (Abubakar, 1992:11). Islam made strict division of the spheres for the different genders. Women were not to be 
seen in the public spheres (Modo1996:99).

Women's participation in public life in Benin Empire was limited (Ikpe, 2004:24). There was no women representation among the various grades of chiefs. Men dominated the different craft guilds and even controlled the markets as agents of the Benin King. The only important female political figure was the Iyaoba (King's Mother) with her court at Uselu. She did not sit in the Oba's council and as such did not take part in decision making. Some of them, such as Iyaoba Idia, reputed to have contributed personally to the success of Esiegie's campaigns against Idah, were powerful and contributed to the successful reign of their sons (Ikpe, 1997:251).They however, did not act as spokespersons for women in Benin.

In the riverine Igbo societies such as Onitsha, Asaba, Osomari and Illah, there was the institution of the queen, the Omu. Though the Omu wielded great authority in the society among the women, her position was based on loyalty to the Obi (king), thus limiting the power of the office (Ekejiuba, 1992:89). Nevertheless, the administrations of the community's affairs in the Igboland was not without due consultation between the men and women groups (Nwankwo, 1999:14; Ajayi, 2007).

Despite the lack of sufficient literature and history that captures the relevance of women in that era and the fact that conventional African history provides only fragmentary images of women, the pre-colonial Nigeria though a patriarchal society, women were not completely left out of the political scene (Ojo, 2003; Olojede, 1990:82 \& Nwankwo, 1999:14)). However, the coming of Westernization destroyed their political positions and then marginalized them in the modern political institutions (Allen, 1972; Sadiqi, 2000:35)

\subsection{Colonial Period}

Women's poor participation in politics, like many other problems in Nigeria, has a deep root in the system carved and imposed by colonialism (Omotola, 2007; Lewu, 2005:65). It began with the colonial occupation, starting with the fusion of the three regions (Yoruba in the southwest, the Igbo in the southeast, and the Hausa/Fulani in the North) to the Nigeria's independence and its governance, and then to the post independent Nigeria (Mba, 1982). Colonialism played a significant role in the political participation of women in Nigeria. The advent of colonialism and its attendant political and economic subjugation subsequently entrenched the masculinity of politics and subordinated the women under the men (Ikpe, 2004:30). Colonial administration created a patriarchy government in which women were not allowed to hold any authoritative positions (Kamene, 1991). Thus, the lack of recognition of the Nigerian women political/leadership role in the mainstream politics in Nigeria today is traceable to colonial invention (Allen, 1972). Colonial administration restructured the feminine relevance in governance by divesting the women of their political powers (Ajayi, 2007:138). This was exacerbated by the policy introduced in which men were believed to have the potential of activeness in the society; and those that were lucky to receive some education got recruited into the colonial overlords. The colonial administration gender policies eroded female participation both in politics and economy as women were denied both electoral and job opportunities (Mba, 1982; Olojede, 1999 \& Ikpe, 2004:30). This practice, to a large extent, served to reinforce and generalize patriarchal values in the country and significantly marked the beginning of low participation of the females in the formal agencies of government, a phenomenon that has continued till date (Enemuo, 1999:232). In fact a section of the women in South Western Nigeria voted for the first time in the nation's electoral history in the 1959 general elections, while their Northern counterparts were disenfranchised and it was not until 1976, fifty-four years after the elective principle was introduced to Nigeria, that the Northern women first enjoyed franchise rights (Ajayi, 2004:138).

In furtherance of the colonial masters' attempt to restructure the traditional African economies in order to make them ready market for European manufacturers and sources of cheap raw materials for their factories, only men 
were granted economic power in the production of export crops while the women were left to concentrate on the production of food crops (Akiyode-Afolabi \& Arogundade, 2003:77). All these have resulted in gender insensitivity in the design and implementation of public policy and have significantly assisted in perpetuating gender inequality in various gamut of social life. At the same time, the masculinity of politics was so entrenched that the machinery put in place during the colonial period systematically rendered women invisible as they were considered unsuitable for the rigours of public life; hence they were not allowed to vote, to contest elections, to sit in parliament or to be employed in the civil service (Akinboye, 2004:237).

Despite the alienation of women from the mainstream of Nigerian politics during colonial administration, the Nigerian womenfolk made itself relevant by its contributions to nationalist movements, which constituted vanguards against the colonial administration. Women political activism dates back to 1929/30 Aba women riot against colonial tax policies. The Ngwa women's opposition against the municipalisation of their community in 1954, the Eastern Region women's opposition to new school fees in 1958; and the series of protests between 1946and 1958 by the Abeokuta Women's Union led by Mrs. Funmilayo Ransome-Kuti were invaluable in the country's struggle for independence (Nwankwo,1996:16). A major landmark achievement in the political development of women during the colonial era was the formulation of a women's political party in 1944 spearheaded by Mrs. Oyinkan Abayomi (Ojo, 2003; Akiyode-Afolabi, 2003:11). At the individual levels however, women, notably including Funmilayo Ransome-Kuti, Margaret Ekpo, Gamboare Sawaba, participated in the anti-colonial political struggle, and took part in the negotiations for independence (Akiyode-Afolabi \& Arogunde, 2003:11).

However, the limited gains made by women did not translate into participation in decision making during this colonial period. Men dominated in the first political parties while actively depending on material and mobilization support from women. The Nigerian National Democratic Party (NNDP), National Council of Nigeria and the Cameroons (NCNC), and Nigerian Youth Movement (NYM) garnered varying levels of support from women's groups. However, women did not feature prominently in the leadership of these and other parties during the nationalist era and after independence (Ahonsi-Yakubu, 2001:151). In the 1958 elections only Wurola Esan got appointed to the Senate of 36 members, while no woman was elected to the 312-member House of Representatives and none was in the federal cabinet (Nwankwo, 1996:17).

\subsection{Postcolonial Period}

The low participation of women in politics was also fostered by the nature of postcolonial politics. Though women's political participation witnessed a rising trend but showed a disturbing low profile participation in political development of Nigeria state (Aina, 2004:227). The acrimonious politics of the post-independence era was detrimental to women's participation. Politics and political parties became ethnic, paternalistic and personality based. Women were expected to support politicians from their own ethnic area without any consideration whatsoever for their personal interests (Ojo, 2003). As party and ethnic allegiance became more important than gender solidarity, women lost their power of collective action, which was important in their agitations during the colonial era (Ikpe, 2004:35).

From 1960 -1965 there were only two female legislators in the federal parliament and three others in the Eastern House of Assembly (Nwankwo, 1996:17, Omotola, 2007:37). Four female legislators in the whole of the country were a number that was so negligible as to give women the necessary influence over decision-making. The imposition of military, an era that followed this period from 1966 did not foster the participation of women in politics and very little was heard of women at the helm of affairs (Anya, 2003). Military rule was an all-male affair and while it lasted women played only a peripheral role (Adeleke, 2002). No woman was appointed 
military governor even though there were some qualified women in the military set-up. However, in 1967, when Nigeria was divided into 12 states, 1 woman was appointed each as commissioners into East Central and Lagos, while Oyo state had two women commissioners (Nwankwo, 1996:17). The Constituent Assembly of the Obasanjo regime in 1975 had no single female members out of its 50 members (Babatunde, 2003). It was the era of military dictators who had little regards for the muchcherished constitutional interest balancing. It also disturbed the proper functioning of women organization as pressure groups since they were banned (Aina, op.cit:227). Women did not feature prominently during the preparations made by the Murtala/Obasanjo regime for returning power to civilians. No woman was appointed to the fifty-member Constitutional Drafting Committee, very few women were elected into the local government councils during the 1976 elections, and only Mrs. Janet Akinrinade was elected to the Constituent Assembly. Four other women were appointed to the 250 member assembly.

The second republic did not witness any significant difference with respects to women political participation despite renewed efforts to give women a chance to contribute to national development (Anifowose, 2004:211). Although from 1979, women have made desperate efforts to enter into representative politics but with little success, women recorded low representation in the Senate, the House of Representative and the States House of Assembly. Only 3 ministers, 1 out 96 senators and 11 out of a total of 450 members of the House of Representatives were female (Aina, 2004:227). In all the 19 states of the federation, there was no female representation in all the State Houses of Assembly, neither was there a female chairperson nor councilor at the local government level (Omotola, 2007:37). With the collapse of the second republic, women again fizzled out of relevance in the two-year regime of Gen Mohammed Buhari (Adeleke, 2002). From the mid-1980s however, the military started appointing a few women now and then to positions of authority. Thus the coming of Gen Ibrahim Babangida in 1985 changed the attitude of military rulers to women leadership. One important aspect of the rising profile of women in political life was the phenomenon of First Lady Syndrome (Aina, 2004:227). This however was nothing but mere personal aggrandizement (Babatunde, 2003). Under this auspices, the Better Life for Rural Women was created and was later renamed Family Economic Advancement Programme (FEAP) by the succeeding First Lady.

\subsection{Women's Political Participation in Nigeria - 1999 - 2015}

The forth republic which began in 1999 saw women taking a similar low participation in the Nigeria's political process. The 1999 general elections saw only 181 positions worn by women out of the 11, 881 available positions throughout the country (Akiyode-Afolabi, 2003:63). The elections saw only five (4.6\%) women out of 109 senators elected into the Senate, while 13 (3.6\%) women were elected into the House of Representatives of 360 seats i.e. 6.3 percent women representation in the national parliament (Ajayi, 2007:139). While there were 36 gubernatorial seats, no female featured. Nigeria had only one female deputy Governor - Chief Kofoworola Akerele-Bucknor, deputy governor of Lagos State (1999 -2003), and of the 990 seats available for the States House of Assembly in the country only 12 (1.21\%) women were elected (Adu, 2008:27). At the local level, out of the 774 local government chairpersons across the nation, only 9 were women and only 143 out of the 8,700 councillors were women (Babatunde, 2003; Anifowose, 2004:210).

The poor performance of women in this election was the basis for the national summit for all women politicians organised by the International Human Rights Law Group, Centre for Development and Population Activities (CEDPA) and Gender and Development Action (GADA) held on June 28, 2002 in Abuja. The objective of the summit was to enhance women's active participation in Nigerian politics (AkiyodeAfolabi \& Arogundade, 2003:64). Despite all efforts geared at improving women's participation in politics in Nigeria, the 2003 elections 
did not witness any significant improvement. In the elections that held that year (2003) only 21 (6.1\%) women out of the 339 member worn seats in the House of Representatives. Similarly, of 109 senatorial seats, only 3 (2.7 $\%$ ) women were elected in to the Senate, which is just 8.8 percent women representation in the national parliament (UNDP Report, 2003:47; Ojo, 2003:16). Of the 36 gubernatorial seats available, no woman was elected and of the 990 seats available for the States House of Assembly in the country, 38 (3.84\%) women were elected (Adu, 2008:27). In 2007 only 25 (6.9\%) women out of the 358 seats were elected into the House of Representatives and 9 (8.3\%) women out of the 109 seats were elected in to the Senate, that is 7.3 percent women representation in the national parliament while, out of the 36 gubernatorial seats available, no woman was elected and of the 990 seats available for the States House of Assembly in the country, 54 (5.5\%) women were elected (Nigeria CEDAW NGO Coalition Shadow Report, 2008:10).

The records from the database of the Independence National Electoral Commission (INEC) showed that in the 2007 elections a total 7160 candidates (both men and women) contested in the April elections. Of this number, only 628 women representing $8.8 \%$ of the total candidates participated. A total 3141 candidates contested for seats in the National Assembly (799 candidates for the senate and 2342 candidates for the House of Representatives). Of this number, only 209 or $6.7 \%$ were women (59 or $7.4 \%$ women for Senate and 150 or $6.4 \%$ women for House of Representative) (Okocha, 2007). The analysis above indicates a 2\%, 4\% and 6\% women representation in 1999, 2003 and 2007 respectively.

However, the trend shows an improvement in women representation. This was due to the conscious affirmative efforts of the Obasanjo administration to involve more women in his political administration. As a result, political parties took a decision to waive for the women the payment of pre-registration levies for political aspirants in the country. In addition the national summit for all women politicians organised by the International Human Rights Law Group, Centre for Development and Population Activities (CEDPA) and Gender and Development Action (GADA) held on June 28, 2002 in Abuja with the objective of enhancing women's active participation in Nigerian politics and the awareness campaigns by these and other gender-related organisations and NGOs spurred women in the federation to vie for political candidature in the 2003 and 2007 general elections (Akiyode-Afolabi \& Arogundade, 2003:64).

In the history of Nigeria, there has been no woman ever elected as state governor, while only 6 women have ever been elected as deputy Governors (from Lagos, Ogun, Osun, Imo, Plateau and Anambra States). Thus the perception that democracy would automatically boost women political participation has not been validated after nine years of return to civilian rule. Nigeria still falls short of the desired result of giving females the opportunities and access to opportunities to advance socially, economically and politically ((Ojo, 2003: Babatunde, 2003; The Nigeria CEDAW NGO Coalition Shadow Report, 2008:3, Adu, 2008:27).

\subsection{Theoretical Framework}

Many political scientists find systems theory as a relevant tool for analysis of multicultural political phenomenon. Frank and Gills (1993:17) for instance, argues the case for applying system theory across disciplines because it provides a "human centric" alternative to the systematic distortions of Eurocentrism" which could help us see 'a common river and unity of history in a single world system (that is) multicultural in origin and expression.' In this view, researchers in the field of social sciences have shown the applicability of this approach to the study of political geography, development studies, gender, ethnic and race relations, international relations and international political economy. Thus, Covington (1998:4) argues that systems theory is all-purpose in that it takes into account numerous systems that interact with other systems which help a researcher to focus attention on important component that might otherwise go unnoticed. He argues further that 
systems theory gains a holistic view of an area of human activity, taking the environment in which a phenomenon is observed as part of this holistic approach.

The development of systems theory for the study of politics however, was first conceived by David Easton in 1953 (Varma, 1975:194). His work was a continuation of the search by social scientists for accurate predictions, using general laws that have universal application for a systemic interpretation of society which was started by a sociologist, Karl Manheim (Newman, 1972:13; Chilcote, 1994:123). According to the Eastonian systems theory, a political system is viewed as made up of interrelated units that function together to make a whole. His concept of political life is that of "a system of behaviour embedded in an environment to the influence of which the political system itself is exposed and in turn reacts (Kaplan, 1968:150). One aspect of the political system cannot therefore be understood thoroughly without studying the other interrelated units. At the centre of Eastonian systems theory is therefore, the formulation of a general framework, a focus on the whole system rather than merely on its parts, an awareness of environmental influences upon the system. Thus Denhard \& Denhard (2006:215) defines a system as a set of regularized interactions configured or bounded in a way that differentiate and separate them from other actions that constitute the system environment. Similarly, Kaplan (1968:150) defines systems theory as the study of a set of interrelated variables as distinguished from the environment of the set.

The theory considers political activity as essentially involving the political system, the input and the output and the environment. Easton views the political system as the basic unit of analysis while the intra-system behaviour of various systems is seen as principal areas of research (Varma, 1975:194). He defines the political system as that system of interactions in any society through which binding or authoritative allocations are made and implemented (Chilcote, 1994:127). The environment consists of the objective conditions and forces that generate the demand and support input. Demands are expressions of opinion that an authoritative allocation with regards to a particular subject matter should or should not be made by those responsible for doing so. Supports are actions or orientation prompting or resisting a political system. Also, the system adapts to its environment through growth and elaboration of its structure made possible by negative entropy. Such a system is also self-regulating through feedback loops which are used by the decider or system decision-maker to achieve its goals and to maintain some sort of dynamic equilibrium (Easton, 1965).

According to this concept, inputs in the form of demands (expectations) and support approach the political system. These inputs (demands and supports) become issues for discussion and resolution. Demands drive the motor of politics, and politics operates to convert demands into authoritative policy outputs. Inputs in this way are processed within the political system during the so-called conversion process and made into binding decisions and policy actions for all members of society in the form of laws and provisions (outputs) (Ikelegbe, 2004:36; Denhard \& Denhard, 2006:215).

The actual conversion of input to output is effected by the various governmental institutions expressly designed for these ends. These Easton referred to as "black box" into which inputs stream and out of which outputs emerge. These outputs in turn create reactions within society and feedback. Outputs that are deemed satisfactory and met the demands of some members within the system generate renewed supports and put to rest the original demands that set the conversion process into motion. Outputs that are judged inadequate may generate negative consequences by eroding supports and dangerously intensifying the level of demands or resulting to new demands on the system. Outputs need to travel full-circle and return, via the feedback loop, to the input side of the conversion process (Rosenbloom, 1993:159; Olawuyi, 2004:33).

Easton analytical framework views the political system as continuously operating mechanism, with inputs 
(demands and supports) going in, and output (authoritative decisions and actions) coming out. According to him, political life forms an open system; open to influences from its environment. The framework however, includes regulatory mechanisms for preventing demand overloads and for maintaining the smooth operation of the system. (Newman, 1972:497; Kaplan, 1968:157; Mahler, 2003:13). Thus the Eastonian system theory involves a general framework, a focus on the whole system rather than merely on its parts, an awareness of environmental influences upon the system, and a recognition of the differences between the political life in equilibrium and in disequilibrium (Chilcote, 1994:127).

Eaton's systems theory is also being referred to as input-output analysis (Mahler, 2003:13). This suggests that the output in form of decisions, policies and actions within the political system is largely a result of the inputs (demands and supports) exerted upon the political system. Although the view by Ikelegbe (2006:37) that some output may be a result of the political system without input from the environment cannot be completely overruled.

It is noted at this juncture, that Gabriel Almond's structural-functionalism approach shares some similar characteristics with Eastonian systems theory in that both emphasize on the whole system as the unit of analysis and views a society as a system of mutually interdependent parts and a change in one segment of a society results in corresponding change in other segments of the society (Malinowski 1944:75; Merton, 1949 \& Radcliffe-Brown, 1950). However, structural-functional teleological assumptions which cannot be scientifically investigated; and its implicit philosophy with a conservative bias toward system maintenance and order rather than change, present some points of departure from the systems theory. Thus critiques believe that Almond's structural- functionalist model presents a static model of society and as a consequence cannot account for change, and that it overemphasizes integration and therefore fail to deal with dysfunction (Holt, 1968:87; Chilcote, 1994:138 \& Newman, 1972).

The adoption of systems theory as the theoretical framework for this study will enhance our understanding of women as subsystem of the Nigerian supra-system whose involvement in the political affairs of the system are to be seen as equally important as other sectors of the society. Political participation is however, a behavioural pattern interconnected with some other factors within the individuals.

Furthermore, political participation, using the systems theory, is an open system, open to the influence of some factors embedded in its environment - the society. Thus women's political participation is a function of some certain factors in the environment which include socioeconomic variables such as the standard of living measured by per capita income and Gross Domestic Product, access to educational and occupational resources et cetera. Another environmental factor is the cultural ideological factor. Most often, the behavioural pattern in a society is guided by the norms and customary practices obtained in that society; so also is women's political participation. The historical legacies such as long tradition of female suffrage, religious traditions etc also constitute environmental factors on which women's political participation responds and reacts to. Of immense significance are the institutional design factors. These include the strength of the country's democracy, the electoral system and gender electoral system. All these factors constitute the institutional design environment that affects women's political participation. Put together, these four factors highlighted above are significant factors within the environment that greatly impact on women's political participation in Nigeria and which as an open system is being affected by them.

The use of systems theory for the analysis of women's political participation thus places before this research work, the immense importance of going deeper into the problems of women's political participation. It helps this research in finding out factors and influences to which women's political participation in Nigeria is open, 
determine the boundaries between one system and another, and speculate as how far the influences that creep through this boundary line are case of damage or destruction to the system and how far they are helpful in maintaining it. Finally, it helps to understand what concept of maintenance would involve, whether stability, equilibrium or survival itself. The study of the challenges of women participation in politics will therefore, not be thorough without the understanding of the influence of these interrelated issues (the economic aspect, socio-cultural background and the political structure of the political system) within the country. All of these are viewed as interdependent in interaction where a change in these elements induces a change in the pattern or level of women's political participation.

While other theories mentioned above fail in one way or the other to look at political reality from a holistic perspective, systems theory dissects political phenomenon as a holistic interconnected unit of the general society. The theory views a political system from a holistic perspective being characterized by the interactions of its components. It is nevertheless, needful to point out that Easton's system theory is not free from some certain loopholes. The theory has been flawed for never realizing its potential as a theoretical framework capable of explaining the operation of the political system (Newman, 1972:497). Furthermore, systems theory like any other theories has been criticized as a mere map of reality and not the reality itself and like most analogies, it is imperfect and exactness is not always to be found in some explanations (Spiro, 1968). However, these flaws notwithstanding, systems theory still enhance our comprehensive theoretical understanding of this research work women's political participation in Nigeria.

\subsection{Women and Nigerian Politics in the Fourth Republic, 1999-2015}

The Fourth Republic began on May 29, 1999 following successful transition programme initiated by the former Head of State of Nigeria, Gen. Abdulsalam Abubakar. The process that led to the birth of the Republic began in 1998 after the controversial death of the then Nigerian military dictator, Gen. Sanni Abacha. Gen. Abacha initially initiated a transition program that would have translated him from a military dictator to a civilian president. This was not realized due to his unexpected death on June 8, 1998 (Akinbi and Adesote, 2014:103). Following his death, General Abdulsalam Abubakar became the new Head of State. He immediately announced that he would hand over power to a democratically elected president on May 29, 1999. As a follow up to the announcement, General Abdulsalam dissolved the existing five political parties registered by the Abacha regime. He voided all the elections that were conducted, and set up another electoral body known as Independent National Electoral Commission (INEC) (Akinbi and Adesote, 2014:101).

The ban on political parties was lifted, and political prisoners were released from detention facilities. The constitution was modelled after that of the ill-fated Second Republic which saw the Westminster system of government jettisoned for an American Presidential system. The electoral body was set up initially to grant provisional registration to nine political parties, with the condition that only those that had more than $10 \%$ of the votes in at least 24 out of the 36 states of the Federation in the local government elections would qualify to contest the subsequent State and Federal elections (Akinbi and Adesote, 2014:104). Eventually, the only three political parties that made the cut and were registered are People se Democratic Party (PDP), All Nigeria People"s Party (ANPP) and Alliance for Democracy (AD). Elections were set for April 1999.

In the widely monitored 1999 elections, former military ruler General Olusegun Obasanjo was elected on the platform of PDP. On 29 May 1999, Olusegun Obasanjo was sworn in as President and Commander in Chief of the Federal Republic of Nigeria (Akinbi and Adesote, 2014:104). Since the inception of the current democratic dispensation in 1999, concerted efforts have been made by womenes groups, women advocates and activists, civil society organisations, Nigerian government and international agencies and donor communities to increase 
women "s participation in both political and public life. Although there is no constitutional provision for the office of the First Lady, Nigeria has paraded several First Ladies in the Fourth Republic and many amongst them played roles that made them prominent. However, statistics revealed very low, disproportionate representation of women in governance. This situation falls well below the recommended $30 \%$ of the Beijing Platform for Action in 1995 and 35\% recommendation of National Policy on Women adopted in July 2000 (Odi, 2012:3.) Although the Nigerian democracy since 1999 provided opportunity for women"s participation in politics, the reality is that the place of women in elective and appointive position with the sixteen years of democratic rule was still low.

But, it was better than during the colonial and second republic. This very low representation of women in governance can be attributed to several factors which will be interrogated later in this paper. There is no doubt that Nigerian women participated virtually in all electoral process in the country since 1999. Women and Nigerian Politics: An Appraisal of 2015 General Elections This section interrogates the extent of women involvement in the 2015 general elections. Areas of their participation include registration, voting, campaigns, contest and so on. It argues that in spite of the increasing number of Nigerian women in politics, the country"s politics is still largely dominated by men. The challenges facing the active participation of Nigerian women in politics such as cultural factor, lack of internal democracy among political parties, gender discrimination, and lack of fund and so on are also analysed in descriptive and analytical manner.

The 2015 General Elections allow democratic nations a chance to celebrate the rebirth of values of popular representation of the interest of the people. Nigerians have, through the recent 2015 General Elections, celebrated this important aspect of democracy. More importantly, the loss of an election by an incumbent Nigerian President, Dr. Goodluck Jonathan to an opposition candidate and the acceptance of the unprecedented situation signify the coming of age of an ideal democracy (The Guardian April 2, 2015:19). The development showed that democracy has actually been consolidated in the country. Fundamentally, our concern here is how this process has advanced the political status of women as well as their role in the unfolding scenario. The outcome of the 2015 General Elections has been argued to be the most expensive in African History (The Guardian April 14, 2015:20).

Meanwhile, it has not indicated a marked departure from the entrenched "tradition" of circumscribing women's role in the political engineering process of even the „benefits" accruing to them for their efforts. Gender cleavages still dictates who wins and who losses election. However, modest progress especially within the more conservative cultural and religious enclaves is exploding myths about the incongruity between politics and gender (Ogunsola, 1993:77). As these women are tried and proven, the trust of the public and the corollary legitimacy of gender representation grow. There are grounds to argue that the representation of women is self-producing and selfsustaining, manifesting as both a catalyst and a consequence of their inclusion. A close examination of the electioneering processes and the voting pattern of the 2015 general elections will assist in validating this position. Electioneering process is made up of the entire or series of activities engaged in by the persons who have agreed to submit themselves to the elections, their political parties, groups, communities, political associations, friends, families and others in order to influence the anticipated preference of the electorate or choosers positively. Simply put, electioneering encompasses all the activities that ginger electorates to support candidates in elections (Akinwalere, 2012:10).

The electioneering process in Nigeria starts with registration of voters in which Nigerian women participated actively (INEC, 2014). This was accompanied by awareness programs conducted by different kinds of agencies, especially on the importance of voters"e registration. In a nutshell, a lot of agencies went all out to facilitate mass 
enlightenment and multi-media campaigns on voter education and promote citizen awareness in order to increase voter turnout during the election and thereby promote electoral and governance accountability, even beyond the elections. The role of the Nigerian Police and other Security Agencies cannot be underestimated here. It was categorically stated during the conference organised on the 8th April, 2015 by the Nigerian Police that the success or failure of any election depends on the stakeholders like INEC, political parties, election observers, media, the Nigerian Police and other security agencies performing their duties effectively and efficiently as expected (The New Dawn, April 10, 2015) Organisations like the International Republican Institute (IRI), CEDPA and United Nations (UN) worked with women in major states and cities to spread the awareness of the need for women "s leadership and to sharpen skills.

Through strategic planning and advocacy workshops, participants expand their political education skills and are encouraged to individually speak out. The Democratic Governance for development project, implemented by United Nations Development Project (UNDP) in partnership with the Nigerian Government trained over 2,043 female politicians and candidates in preparation for electoral processes at both national and state levels. Focused programmes, like those organized by the IRI and UNDP, truly make an impact on female political engagement (UNDP, 2014). Towards this, the Nigerian Women Trust Fund supported the „Preparation towards the 2015 General Election: Enhancing citizen participation through Civil Society Organisationse at a Conference in Abuja, Nigeria on 8th April, 2014. The meeting is one of the many fora for the Civil Society Organisations (CSOs) to actively engage with the Independent National Electoral Commission (INEC) enroute to a fairer 2015 election process (Onyekwelu, 2014:1). Also, the Trust Fund whose multimedia campaign focuses on the benefits of increased women "s political participation; the womene's political education session conducted by the non-partisan Women in Politics Forum to increase women "s chances to run successful campaigns for office. It should be noted that INEC introduced an easily accessible means of continuous voter registration via email and SMS, and called on the help of CSO $\mathrm{CS}^{\text {s }}$ to educate the voters on its use. The women took advantage of this and registered enmasse towards the 2015 general elections to make up the total number of $68,833,476$ registered voters in the country, both male and female (INEC, 2014).

The Resident Electoral Commissioner (REC) of Rivers State, Dame Gesila O. Khan observed in a paper on how INEC supports women participation in the 2015 Elections, the poor participation of women in politics vis-à-vis their numerical strength and relevance in governance has propelled the commission to support them both as voters and candidates. She opined that "Available statistics show that over $49 \%$ of the Nigerian population are women, yet only $7 \%$ are involved in governance", adding that Nigeria has a huge resource base of women whose contributions are currently not being enjoyed". Other reasons she advanced for supporting women include their equal constitutional rights to political participation as men, increasing their number in governance to fulfil Nigeria"s local and international commitments for gender parity among others (INEC Admin, 2015).

Mrs Dame Judith Amaechi, the wife of the governor of Rivers state also encouraged the youths to shun violence as 2015 general elections as it gather momentous, that the youths must intensify their efforts to educate and re-orient themselves against violence and from all forms of victimisations. With this, the use of youths for violence was minimised during the 2015 general elections (Elendu Report, Thursday 12, 2015). A lot of women leaders and advocates were involved in the electioneering process of the 2015 general elections. Campaigns and Rallies When the 2015 general elections were approaching, candidates from various political parties launched their campaigns in full swing. The Nigerian women participated actively in the 2015 general elections campaigns and rallies. The women came all out to support the candidates of their choice to support them in campaigns and rallies. Dame Patience Jonathan and Hajia Aishat Buhari campaigned rigorously for their 
spouses. Dame Patience Jonathan was seen severally at campaigns for the return of her husband while Hajiya Aisha Buhari appeared for the first time at a campaign rally on the 13th of January, 2015 at the M.K.O Abiola Stadium, Abeokuta, Ogun State. She engaged in campaigns that further confirmed her support for her husband. She was involved in mobilising women to vote for her husband and engaged the crowd at rallies on issues and promises by her husband (The News Magazine, 2015.13). She also demonstrated her passion for the development of Nigerian women at a campaign rally in Edo State, where she assured women that her husband would initiate policies that would guarantee their living standard. Also, the Nasarawa State governor"s wife, Hajiya Salamatu Al-Makura called on the women in the country to see the postponement of election by six weeks as opportunity to go and collect their Permanent Voters Card (PVC) when she played host to some women groups that paid her a courtesy visit in her office in Lafia (News Agency of Nigeria, Feb. 19, 2015).

In buttressing the fact that women participated actively in the campaign rallies of 2015 general elections, women and youths numbering over 5,000 staged a mega rally in support of APC presidential flag bearer, Gen. Muhammadu Buhari and his running mate, Prof. Yemi Osinbajo. The rally took place simultaneously in Afikpo Local Government area and Abakaliki, the state capital. They matched through Ebonyi APC campaign headquarters along old Enugu road through major streets in the two cities, chanting songs in support of the APC standard bearers (Osun Defender, 2015). All these revealed the level of women involvement in the 2015 general elections. They also featured in the cultural events and entertainment, mobilization, catering and event managements as well as in clerical duties.Furthermore, in Aisha Buhariees efforts in mobilizing women and youths to support and vote for her husband during the campaign period, she reiterated her gratitude to the efforts of the women during the 2015 general elections that brought her husband to power.

In her speech during the „Appreciation Dinnere organised recently at the government house, Abuja for women and youths on the success of the campaigns to team work of the women and youths that helped vote her husband into office. With her agenda on ,focusing on women issues" the wife of the president hoped to see more women in the legislature, from the local level, while she also observed the decline of women in the legislature as opined in the body of this paper, Aisha Buhari hopes to help reverse the situation and believed that empowerment from the ward level would better affect ordinary women on the streets. She also quoted people saying that her husband earned up to „four million votes "e as a result of her campaigns (The News Magazine, 2015.16). This indicates to a large extent the importance of the role of women during campaigns and rallies for their husbands. On the other hand, it has also been said in some quarters that the role of Dame Patience Jonathan during the 2015 general election campaigns contributed to her husband"es defeat at the polls. However, with high level of participation of women in the electoral processes, the following tables below however indicate the level of representation of women in the 2015 elections in Nigeria.

\section{Women Participation in Elective Positions \\ 5.1 The Presidential}

Professor Oluremi Sonaya, the first woman to ever qualify as a presidential candidate in Nigeria came on board in the 2015 general elections. She was involved in a primary with three other aspirants and emerged as the party"s nominee as the presidential candidate of the party. The presidential result revealed that women participation can actually influence the politics of the country. The only female candidate polled some votes in all the states of the country. The result showed some reasonable votes where male candidates were unable to get as much. For example, in Nasarawa State where Citizens Popular Party (CPP) candidate polled four votes, she polled forty eight votes. Also, the total number of votes she secured surpasses that of HOPE Democratic Party and United Democratic Party (UDP) parties during the election. While the total number of votes for HOPE was 
7,393 and UDP was 9,147 votes, KOWA party had 12,524 votes (The Punch, April 1, 2015).

With this development, experts and gender activists have continuously advocated the active participation of women in governance for the good of society. The result of the just concluded 2015 general elections in the country has however, not shown improved women representation in elective positions in the country. It should be noted that out of the fourteen candidates that contested for the seat of the president, the only woman amongst the contenders came out in the twelveth position. Just as men have always dominated the National Assembly, the 2015 election result does not present a different picture in the number of women who will represent their constituencies in the next four years. However, many Nigerians saw in the audacious candidacy the possibility of real change and a clear departure from what the country experienced so far as a nation.

\subsection{The Gubernatorial}

The gubernatorial candidate of the All Progressive Congress, APC in Taraba state Aisha Jumai Al-Hassan would have made history in the last gubernatorial election in the state as the first woman to scale the hurdles of electioneering campaign and break the jinx that has befuddled Nigerian women over the years from emerging successful at the polls as governors, but for the outcome of the election which was not in her favour in the gubernatorial election. „Mama Taraba ${ }^{e e}$ as she was fondly called, almost made it but then, the near success syndrome that has been the lot of many Nigerian women in politics cut short her joy. Her expectations were high that she would emerge successful considering the direction of some results earlier reeled out by INEC. But suddenly, the result of the election was declared inconclusive and then, a re-run that finally dashed her hope when the PDP candidate was declared winner.

\subsection{The Legislative}

Table 1. Senate

\begin{tabular}{llllll}
\hline \multirow{2}{*}{ Year } & \multicolumn{5}{c}{ Number of Seats and Percentages } \\
\cline { 2 - 6 } & Number of seats & Men & $\%$ & Women & $\%$ \\
\hline 1999 & 109 & 106 & 97.2 & 3 & 1.8 \\
\hline 2003 & 105 & 96.3 & 4 & 3.7 \\
\hline 2007 & 100 & 91.7 & 9 & 8.3 \\
\hline 2011 & 102 & 93.6 & 7 & 6.4 \\
\hline 2015 & 101 & 92.7 & 8 & 7.3 \\
\hline
\end{tabular}

Source: The Nigerian CEDAW NGO Coalition Shadow Report (2008), New York, United Nations Committee on Elimination of all Forms of Discrimination against Women. Adapted from Ojo, John Sunday (2013)

In all, eight women made it to the 109 members $^{\text {ee }}$ senate as opposed to the seven elected in 2011 . Three of the eight women senators are of the All Progressive Congress (APC) while the rest five are from the People Democratic Party (PDP). The 2015 general elections was able to add one female to the seven in the 2011Senate. This is still far from what is expected of a balanced assembly

Table 2. House of Representative

\begin{tabular}{llllll}
\hline \multirow{2}{*}{ Year } & \multicolumn{5}{c}{ Total No of Seats and Percentages } \\
\cline { 2 - 6 } & Number of seats & Men & $\%$ & Women & $\%$ \\
\hline 1999 & 360 & 347 & 96.4 & 13 & 3.6 \\
\hline 2003 & 339 & 318 & 94.2 & 21 & 5.8 \\
\hline 2007 & 360 & 333 & 92.5 & 27 & 7.5 \\
\hline
\end{tabular}




\begin{tabular}{llllll}
\hline 2011 & 360 & 335 & 93.1 & 25 & 6.9 \\
\hline 2015 & 360 & 346 & 96.1 & 14 & 3.9 \\
\hline
\end{tabular}

Source: The Nigerian CEDAW NGO Coalition Shadow Report (2008), New York, United Nations Committee on Elimination of all Forms of Discrimination against Women. Adapted from Ojo, John Sunday (2013)

The table above indicate a drop from the 2011 general elections. There was a steady increase in women representation in the House of Representatives since the inception of the Fourth Republic in 1999. But during the 2015 general elections, the percentage of women representation dropped from $25 \%$ to $14 \%$. This is not a good development. However, there is this hope that the new government will compensate the women in the appointive position like the President Jonathan administration did for the women folk.

Table 3. State Houses of Assembly

\begin{tabular}{llllll}
\hline \multirow{2}{*}{ Year } & \multicolumn{5}{c}{ Total Number of Seats and Percentages } \\
\cline { 2 - 6 } & Number of seats & Men & $\%$ & Women & $\%$ \\
\hline 1999 & 978 & 966 & 98.8 & 12 & 1.2 \\
\hline 2003 & 951 & 912 & 96 & 39 & 4.0 \\
\hline 2007 & 900 & 843 & 94.2 & 57 & 5.8 \\
\hline 2011 & 832 & 93.1 & 68 & 6.9 \\
\hline 2015 & & & & \\
\hline
\end{tabular}

Source: The Nigerian CEDAW NGO Coalition Shadow Report (2008), New York, United Nations Committee on Elimination of all Forms of Discrimination against Women. Adapted from Ojo, John Sunday (2013)

NA - Not Available

Tables 3 reveal that in 1999 House of Assembly elections, women constitute $1.2 \%$ while the men folk comprise $98.8 \%$; in 2003, women were $4 \%$ while men constitute $96 \%$. In 2007 women were $5.8 \%$ while men were $94.2 \%$. With little increase, women were 5.8\% in 2011 while men were $93.1 \%$. The 2015 general elections reveal that the Senate has $7.3 \%$ of women

\subsection{Deputy Governorship Position}

The gubernatorial elections produced four women deputy governors. They are Oluranti Adebule (Lagos State), Mrs Yetunde Onanuga (Ogun State), Ipalibo Banigo (Rivers State) and Cecilia Ezeilo (Enugu State). It is disheartening to observe that only few women emerged winners in the various positions they contested for both at the party primaries and in the general elections. Despite improved political consciousness of women and the various objectives of the National Gender Policy, it is disappointing that women still occupy less than eight percent of elective positions at all levels of governance in the country. The "domino theory" of patriarchy and masculinity which predominantly characterised the Nigerian society is still a dominant force that controls the entire polity (Oke, 2013:67).

Men still exclusively dominate Nigeria's political landscape and this reflects in the gap in the number of seats won in general elections from 1999 till date on the basis of gender as captured by the tables above. Be that as it may, women have benefitted more in selective or appointive positions since 1999 and in fact, in some instances, they have been compensated with 35\% inclusion in all appointive positions (Oke, 2013:67). Women have occupied many sensitive appointive positions which have expectedly improved their voices in public affairs. For example, Dr Okonjo Iweala (who served as Minister of Finance and coordinating minister for the Nigerian 
economy), no doubt, has played significant role in not only the political economy of Nigeria, she has also set a pace at the international scene. In a nutshell, the empirical evidences as given above depicts the potency or otherwise of the contribution of women in the formation and restructuring of the Nigerian economy and politics in general. It then means that women can play active roles in shaping the direction of Nigerian politics even far beyond the imaginations of the male folk.

By any standard, however, women participate in politics as voters, party supporters and usually attend political rallies in large number. Some even run for top political offices (the example of Sarah Jibril and Professor Oluremi Sonaya of the KOWA Party who contested for the office of President with Goodluck Jonathan and Muhammadu Buhari respectively and Hon. Mulikat who unsuccessfully (albeit robustly) vied for the seat of Speaker, House of representative is apt in this direction). The 2006 census puts Nigerian women at about half the population of the entire country (Channels TV, 2012 August 2). Despite this numerical advantage and the massive participation in voting, less than $20 \%$ of political offices are held by women. For all intents and purposes, it appears that the Nigerian situations seem to defy the political theory that political power derives from political participation because women participate fully in elections in Nigeria but without full representation (Jibrin and Salihu, 2004:)

Nigerian women have about the lowest representation of 5.9\% in the national legislature when compared to most other African countries. For example, Uganda has 34.6\%, South Africa (43.2\%), Ethiopia (27.7\%), Cameroun (20\%), Niger (12.3\%) and DR Congo (8.0\%) (Daily Times, May 18, 2012). For Nigeria women, particularly in areas of political representation in governance the percentage is $7 \%$, the lowest in the world (Vanguard Newspaper, January 21, 2013). Women representation in Nigeria politics has, over the years, been less than encouraging. This poses a challenge and narrows the chances of getting more women in decision-making structures. Women have actually proved their strength and competence in the society in all spheres even in male dominated professions but women involvement in public decision making processes in the emergent Fourth Republic in Nigeria has been characterized by low representation.

Instructively, women have particularly demanded the implementation of affirmative actions towards the integration of at least 35\% of women in all elective positions and in fulfilment of United Nations agenda for gender mainstreaming (Oni, 2014:107). Women political empowerment and development as enshrined in Nigeria"s National Gender Policy should be adopted. It is useful to mention that globally, women representation has increased from 13\% to 18\% (Igbuzor, 2014:77). But it is worrisome to note that while increase in Africa is phenomenon from $10 \%$ to $17 \%$, the growth rate in Nigeria remains stunted and even declining. The clamour for the attainment of the 35\% affirmative action for women political integration has remained a far cry from what is obtainable in other continents. Igbuzor, 2014 attempted a comparative assessment thus: Burundi has 30\% quota for women representation in the constitution while there is 50\% local representation in South Africa Local Government. African National Congress (ANC) has 30\% women representation enshrined in the party's constitution.

A comparative study of election results from 1999-2015 reveals vividly that elective positions still elude women despite huge investments in mobilization, advocacy, lobbying and many others. However, it is impressive to observe that women public consciousness has improved significantly in the Fourth Republic. More women have put themselves forward in virtually every position to be contested for in the current political dispensation unlike the situation previously. Women political consciousness was particularly fascinating and impressive in the 2015 general elections. But this has not translated to meaningful inclusion in the political process as expected. As a result, it would be necessary to look into the challenges facing the involvement of women in the Nigerian 
politics and which has also affected their representation in the 2015 general elections. The challenges facing the Nigerian Women in Politics Over the years, Nigerian women have continued to record very poor performances in elective political offices. This is largely due to the sentimental attachment on feminine gender. Although they have been playing crucial role in political life of the country, this has not yielded results in terms of their performances when it comes to elective offices.

The following are some of the challenges considered to be affecting the women in elective positions:

Cultural and Religious Factors

Culture and religion are strong factors inhibiting women involvement in politics in Nigeria. The socio-political and religious values constrained women to be fully involved in political participation, especially in the northern Nigeria where Purdah System is more pronounced. Even in other climes there are also inhibiting socio-cultural practices like polygamy where the husband in Yorubaland will have a favourite among his wives who represents him in some occasions. Gender Imbalance Nigeria as a Federation operates the Federal Character Principle which is the attempt to eschew group imbalance in public institutions and affairs. The definition of that "group" does not include gender in the conception and implementation of the principle. Understandably, there are legal provisions which tend to guarantee the equality of all individual and groups including women. But there is no legally backed affirmative action to promote gender balance. This has been fostering discrimination against women in employment in government and the private sectors. This may be as a result of patriarchy, which sees the man as the breadwinner and head of the family and must, therefore, be given preference over women in employment (Jegede, 1994: 101). The military is a good example where women were excluded in the combatant corps thereby automatically excluding them in high-powered political decision-making in the organisation.

\subsection{Lack of Internal Democracy}

Political parties in Nigeria are fond of selecting a consensus candidate as flag bearers of the party during the elections. Democracy is not usually allowed to play its full part in elective positions. In a situation whereby a candidate is highly favoured, the political leaders will not allow contest to have its full sway. Within a period of time, they would have declared a consensus candidate to the disappointment of other candidates who are willing and even in some cases more qualified for the position.

\subsection{Lack of Funds}

Finance is a major factor for the survival of every organisation. It is the bedrock upon which successful institution rests. First, to understand the financial problem of women in Nigerian politics, we have to fathom the type of politics in Nigeria. Politics in Nigerian parlance could be understood within the framework of monetization. Any political contestant must have prepared to acquire the entire necessary wherewithal to make him or her successful in the electoral contest. The cost of running electoral contestation in Nigeria is too exorbitant for women to bear (this includes; party nomination form which runs into millions of naira, election campaigns, gifts to god fathers, people mobilization and money for political party leaders, etc). This financial burden discourages women to run in democratic contests. Women Issues Women are said to be their own worst enemies. An article by Women in Higher Education pointed out that relationships are central to women"s lives and they expect their relationships to be on a level playing field, and that when something - anything affects this balance, such as promotion, it raises feelings of insecurity.

The article underscores the reasons why on entering a gathering, women quickly, but silently, do an assessment and judge themselves on looks, age and sex appeal. (Punch 4: 2015). Though women hate to admit it, they still judge others on these. When women find themselves in a marginalised position within the family, they may react by trying to be extremely good, or go on the offensive to prove they are smarter and better than other 
women. This implies that women are more likely to judge their abilities against those of other female colleagues than males. Generally, jealousy is usually the problem but it has not been subjected to any serious research. It ${ }^{\text {tes }}$ just a feeling, and women themselves do confess to it.

This is manifested in the "pull her down-syndrome" where women condemn female political aspirants by calling them names, assassinate their character and engage in smear campaigns thereby making women enemies of one another. Casual observation will support that women while in authority may be a little harsh over their female counterparts, and men are not spared sometimes. This also is a major challenge to women voting for their counterparts in politics and this could have been to a large extent a factor responsible for low women support for Oluremi Sonaya of KOWA Party as a presidential candidate in the 2015 general elections. Violent Nature of Nigerian Politics The challenge of Violence in Nigerian politics, which has been part and parcel of Nigerian democracy pose an obstacle to women "es interest in party politics. During the periods of campaigns, the political atmosphere is usually characterised by waves of assassinations, thuggery, murders, arson, looting and kidnappings. The incidence of Mrs Emily Olufunke Omope-Aborishade also known as „Ms Thatcher" who was bathed with acid in Ekiti State in 2002 for her unwavering determination in the state politics was a case in point. The physical battles which often accompany electoral contests in Nigeria need to be addressed and this can be spearheaded by civil society organisations. Women Education The problem of women education generally starts with lack of access to education like men.

Once the girl child is withdrawn untimely from school for socio-economic reasons, the boy continues to go further. This deprived most Nigerian women from formal education. Meanwhile, education is a necessary pre-requisite for securing high-powered jobs in the public and private sectors. Without this important ,ingrediente, women are unable to put in their best towards personal and national development. This again is a shortcoming in women participation in politics generally. In sum, it can be said that women representation at all levels of governance in Nigeria is highly disproportionate to their numerical strength. Thus, while the aforementioned factors might have inhibited the significant participation of women in politics, they do not provide all the explanatory variables. Our perception of the nature of the role of women in the society is prejudiced against women. Redefining that perception in manner favourable to active women participation, therefore is a significant step to addressing the problem of gender imbalance in Nigeria.

However, in order to succeed, women must cooperate among themselves to win in a man"s world like Nigeria and refused to be used to pull down or limit their fellow women in whatever field of endeavour. They must agree to work together. Women have not been using their numerical strength to their advantage. It is believed that if all women will determine to give their votes to women aspirants, the chances will be quite high for women aspirants. But instead, you see men marginalising women in political party leadership with most parties hierarchy dominated by men. This could be linked to the comparably poor financial status of women to fund or support party activities in the country.

\subsection{Policy Recommendation}

The phenomenon of the age-long historic dismal participation of women in the formal arena of politics in Nigeria can be nipped in the bud. It will only take a consciously determined effort of the Nigerian government to be truly committed to pursuing the course of women empowerment rather than mere political aggrandizement. In order to achieve the goal of improved women's political participation, the following policy recommendations are suggested. Nigeria is a signatory to the Convention on the Elimination of All forms of Discrimination Against Women (CEDAW). However, this has not become laws in Nigeria.

Therefore CEDAW should be domesticated and its Article 1 - 16 should be incorporated in to local laws in 
Nigeria immediately. This will expunge the conflicting and discriminatory provisions in Nigerian Statutory, Customary and Religious laws that reinforce male supremacy and perpetuate patriarchal system, e.g the Sharia law. The domestication of CEDAW will also prohibit the reinforcement of patriarchy structure and men's domination by the major agents of socialization - The family, schools religion institutions and the mass media. Affirmative action measure is a key strategy to redressing gender imbalance in politics. The government of Nigeria though shares this approach in the country, an idea that was instrumental to the free nomination fee for women political aspirants, however, no conscious effort is made by the government for the entrenchment of such as a constitutional policy for implementation in Nigeria. This study upholds that affirmative action in the country must not be mere voluntary action, but explicit specifications and clear guidelines for modalities and implementations that enhance women's empowerment should be developed. The National Assembly should pass an Electoral bill into law specifying what affirmative actions are adopted to enhance women's political participation in the country. For instance, 50\% of financial cost of registration as a candidate for political positions and election campaign should be borne by the government. Every national political party should reserve $30 \%$ of all elective positions for women.

The Independent National Electoral Commission (INEC) should ensure that this policy is obeyed and any political party that fails to follow it should be disqualified. There is a clear consensus in literature and among respondents in this study that electoral quota system is an effective tool for addressing low women's political representation. Therefore, by a constitutional provision, 30\% of the seats in the National Assembly, States' House of Assembly and Local Government Councils in Nigeria should be reserved for women and this quota system of female gender representation should reflect in all their committees. Government should partner with women's movements and civil society to embark on aggressive awareness and enlightenment campaign towards changing societal perception that women are inferior to men. By engaging a number of these women's movements such as Gender and Development Action (GADA), Gender Rights Advancement and Development (GRAND), Civil Liberties Organization, Rural Women Empowerment Network (RUWEN), Legal Defence and Assistance Project (LEDAP), Women's Consortium of Nigeria, Women Law Development Centre, Gender and Constitution Reform Network (GECORN), National Council of Women Societies (NCWS) Women in Nigeria (WIN) et cetera.

The Ministry of Women Affairs and other government machinery for women's advancement and development should be strengthened. The ministry should be equipped with modern information storage and research facilities to investigate and document the situation of women. This ministry is nothing but mere political propaganda that lack tangible and practicable realistic policies and plans for women empowerment. It is unfortunate that this ministry could not even provide up-to-date statistical records of women in political offices in their states. One wonders what such institution can offer with respect to women empowerment when it lacks adequate information about the issue it is created to address. Economic empowerment strategies at the level of policy-decisions and policy framework need to improve lives of poor women and men in equal measure. Such strategy must find ways of affecting lives at the grassroots and not be limited to the states' capitals. This is important if women and men from all strata are to participate in political development of the states. On this note, loan scheme with minimal interest rates should be made available for women to enable them embark on small and medium scale business entreprise.

In addition, the Central Bank of Nigeria should mandate commercial and microfinance banks to remove the stringent regulations that make loans inaccessible for the common man. It should give directive to these financial institutions to give special priority to women who seek loan for small and medium scale entreprise. 
Banks who default in this directive should be severely sanctioned. There should be a reformation of customary and religious institutions of the states so as to avoid discrimination against women's involvement in public life. The patriarchal structures that reinforce power imbalance between women and men should be dismantled. Nigerian government should therefore abolish all statutory, religious and customary laws and practices that subordinate women to men. Government should consciously mainstream women's perspectives and issues in all policies, plans and progammes in public and private spheres. Child care and other social facilities such as healthcare services, Daycare services, Nursery and Kindergarten Schools should be provided in the various major towns with affordable charges to reduce the burden on women who have to bear the responsibility for family and community sustenance in addition to their major role as wives, mothers and economic contributors. These facilities will help free women for effective participation in the public sphere and make them available for more productive ventures.

Government should engage the support of the mass media for vehement campaign against women subordination, discrimination and stigmatization in the society. The Ministry of Women Affair should have a periodic campaign programme via the mass media in this regard. The current majority electoral system should be changed in favour of proportionate representation. These will not only encourage political parties to field women as candidates for second seats; it will also reduce the "do or die" political struggle among political parties engendered by the principle of "winner takes all" that is characteristic of majority electoral system. Education of women is useful to destroy inferiority complex and to give aspiring women courage and confidence to compete with men. Women education should target the adult population both in the cities and rural areas. Nigerian Government should therefore establish evening and week-end education programme in the states for adult women who as a result of one limitation or the other could not attend the formal education. National Youth Service Corps members posted to this states should be engaged in this programme instead of deploying them to various organisations where they are rejected or redundant for a whole year of their services. Graduates who roam about the streets in search for jobs can also be meaningfully engaged in this programme.

Lastly, the creation of a political environment supportive of and conducive for women's participation is a responsibility of the government. Government must curb the culture of electoral violence and the use of political thugs and gangsters to suppress and witch-hunt political opponents in the country. Election Task Force should be established by the government with membership drawn from The Nigerian Police should be on ground throughout election periods for immediate investigation of the use of political thugs and gangsters during political campaigns and voting by political parties or aspirants, and conviction of such acts through the adjudication of Election Tribunal should lead to automatic disqualification of such political party or aspirants by the Independent National Electoral Commission (INEC).

\section{Conclusion}

This study has examined the spate of women's participation in politics in Nigeria, under the new dispensation of a democratic government since 1999. Despite global campaign for gender equality, women's political representation in the country has failed to achieve the critical mass of 30\% women's representation in the country's parliament. The country's socioeconomic factors, political structures, historical heritages, political thuggery and gangsterism, societal norms and beliefs have created a culture that alienates women from the main stream of Nigerian politics. The imperative of democratic consolidation in Nigeria requires that women, who constitute half of the national population, should find prominence in the mainstream political development of the nation since democracy is only achievable on the altar of popular participation of every citizen of the society, males and females alike. It is therefore conclusive that any corrective measure adopted to address the 
low participation of women in Nigerian politics will only be superficial unless the nation's socioeconomic, cultural and political factors that limit women empowerment are decisively addressed.

Furthermore, the various obstacles and challenges identified can be addressed by both political and legislative commitment. The review of the 1999 constitution must state specifically the principles and methodology of affirmative action as exemplified in Uganda, South Africa and Rwanda. Affirmative action and quotas have been used across the globe to address the need to close the gender-gap in political-bureaucratic development. Nigeria can benefit from these "best-practices". Despite unprecedented human development efforts, a widespread inequality between genders still persists in access to political terrain. This is as a result of decades of neglect to focus on gender issues. Gender mainstreaming has become the catch phrase for narrowing the gendergap and should provide the significant impetus for political development that will correct generations of social injustice in gender relations in Nigeria.

\section{References}

Adu, Olufunmilayo (2008) "The Missing Link: Women's Representation and Participation in Nigeria's Electoral Politics and their Effects on Nigeria's Development". A PhD Thesis. Dept of Political Science. Haverford College, USA.

Ajayi, Kunle (2007) 'Gender Self-Endangering: The Sexist Issue in Nigerian Politics'. Journal of Social Science Vol. 14. Number 2. pg 137 - 147).

Akiyode-Afolabi, Abiola \& Lanre Arogundade (2003) Gender Audit - 2003 Election and Issues in Women's Political Participation in Nigeria. Lagos: Women Advocates Research and Documentation Centre.

Alexander, Amy C. \& Welzel (2007) Four Theories Tested on Four Different Aspects of Gender Equality. Irvine: University of California.

Alkali, Richard (2007) Nigeria: "The Challenges Women Face in Politics". Retrieved on April 18, 2008 from the website (www.jstor.org)

Amadiume, Ifi (1997) Re-inventing Africa: Matriarchy, Religion and Culture. New York: Zed Books Ltd.

Anifowose, Remi (2004) Women Political Participation in Nnigeria: Problems \& Prospects." In Akinboye (ed) Paradox of Gender Equality in Nigerian Politics. Lagos: Concept Publications.

Attoe, Effah (2002) "Problems Militating Against Women in Politics." Retrieved on 18www.onlinenigeria.com) th April, 2008 from the website (

Badawi, Ghaji (2007) "Libraries and Women's Participation in Nigerian Politics” IFLA Journal, Vol. 33, No. $2,168-175$

Bari, Farzana (2005) Women's Poliovical Participation: Issues and Challenges. United Nations: EGM/WPD-EE/2005/EP.12

Bruce, Adeyinka A. (2004) "Essentialising Gender Justice and Women's Empowerment." In Akinboye (ed) Paradox of Gender Equality in Nigerian Politics. Lagos: Concept Publications.

Cain, M., Sheda Rokeya Khan and Shamsun Nahar (1979) 'Class, Patriarchy, and Women's work in Bangladesh' Population and Development Review 5, pg 405 - 438

Ezeigbo, Akachi (2004) 'Literature: A Tool for Gender Activism in Nigeria.' In Akinboye (ed) Paradox of Gender Equality in Nigerian Politics. Lagos: Concept Publications.

Fashola, Raji Babatunde (2008) "300 Days in Office". A Publication of the Lagos State Ministry of Information and Strategy.

GADA (2008) "Gender Analysis of the Executive and Legislative Positions (2007 Elections)". A Publication of Gender And Development Action. Surulere, Lagos. 
Georgina, Waylen Third World Politics. Buckingham: Open University Press.

Henderson, Sarah (2006) Participation and Protest: Women and Politics in a Global World. Oxford: Oxford University Press.

Ikpe, Eno Blankson (2004) 'The Historical Legacy of Gender inequality in Nigeria.' In Akinboye (ed) Paradox of Gender Equality in Nigerian Politics. Lagos: Concept Publications.

Inter-Parliamentary Report (2007) Women in Parliament in 2007: The Year in Perspective. Retrieved on 18th September, 2008 from website (www.ipu.org).

Pasaud-Becane, Genevieve (1999) Participation of Women in Political Life. Geneva: Inter-Parliamentary Union

Peterson, Spike V. \& Ruysn Anne Sisson (1999) Global Gender Issues (2nd Ed). Colorado: Westview Press.

Krook, M. L. (2005) Comparing Methods for Studying Women in Politics: Statistical, Case Study, and Qualitative-Comparative Techniques. Washington DC: American Political Science Association.

Lewu, M. A. Y. (2005) "Women in Nigerian Politics". In Hassan A. Saliu (ed) Nigeria Under Democratic Rule (1999 - 2003) Vol 2. Ibadan: University Press plc.

Miki, Caul (1997) “Women's Representation in Parliament: The Role of Political Parties.” Irvine: Center for the Study of Democracy. Retrieved on 30www.democ.uci.edu/publications/papersseriespre2001/caul.htm) th April, 2008 from website (

Norris, Pippa (2000) "Positive Discrimination Policies for Women." In Klausen Jyette \& Charles S. Maier (ed.) Has Liberalism Failed Women? Parity, Quotas \& Political Representation. New York: St Martin’s Press.

\section{Copyrights}

Copyright for this article is retained by the author(s), with first publication rights granted to the journal. 